\title{
EGU2012 SM1.3/GI1.7 session: "Improving seismic networks performances: from site selection to data integration"
}

\author{
D. Pesaresi ${ }^{1,2}$ and F. Vernon ${ }^{3}$ \\ ${ }^{1}$ OGS (Istituto Nazionale di Oceanografia e di Geofisica Sperimentale), Udine, Italy \\ ${ }^{2}$ Istituto Nazionale di Geofisica e Vulcanologia, Roma, Italy \\ ${ }^{3}$ Scripps Institution of Oceanography, San Diego, USA
}

Correspondence to: D. Pesaresi (dpesaresi@inogs.it)

Received: 27 March 2013 - Revised: N.A. - Accepted: 4 April 2013 - Published: 30 April 2013

\begin{abstract}
The number and quality of seismic stations and networks in Europe continually improves, nevertheless there is always scope to optimize their performance. In this session we welcome contributions from all aspects of seismic network installation, operation and management. This includes site selection; equipment testing and installation; planning and implementing communication paths; policies for redundancy in data acquisition, processing and archiving; and integration of different datasets including GPS and OBS.
\end{abstract}

\section{Introduction}

The history of seismic network sessions at European Geosciences Union (EGU) General Assemblies started in 2010 with the SM1.3 "Seismic Centers Data Acquisition" session (Pesaresi, 2011 and SM1.3 Seismic Centers Data Acquisition, 2010), where the Convener Damiano Pesaresi supported by the ODC Director Co-Convener Reinoud Sleeman chaired a session of 7 oral and 16 posters. A similar session was later the same year held at the XXXII European Seismological Commission (ESC) General Assembly: "SD1, 3 Seismic centers data acquisition", conveners D. Pesaresi and R. Sleeman, with 15 oral presentations.

The history continues in 2011 with the SM1.3/G3.8/GD3.7/GI-19/TS8.7 "Improving seismic networks performances: from site selection to data integration" session (SM1.3/G3.8/GD3.7/GI-19/TS8.7 Improving seismic networks performances: from site selection to data integration, 2011) where the Convener Damiano Pesaresi supported by the Co-Conveners John Clinton and Robert Busby chaired a session of 9 oral and 20 posters.

\section{The EGU2012 SM1.3/GI1.7 session}

In the EGU2012 SM1.3/GI1.7 "Improving seismic networks performances: from site selection to data integration" session (SM1.3/GI1.7 Improving seismic networks performances: from site selection to data integration, 2012) the Convener Damiano Pesaresi supported by the Co-Convener Frank Vernon chaired a session (Fig. 1) of 6 oral (Table 1) and 22 posters (Table 2).

The 28 presentations comes from 13 countries (USA, Ireland, Switzerland, UK, Saudi Arabia, Egypt, Austria, Japan, Slovenia, Italy, Finland, Greece, France) from 4 different continents (North America, Europe, Africa and Asia), which well fits the goals of the European Geosciences Union.

Presentations worth mentioning in the session were:

1. "Integration of Infrasound, Atmospheric Pressure, and Seismic Observations with the NSF EarthScope USArray Transportable Array", by F. Vernon, J. Tytell, M. A. H. Hedlin, K. Walker, R. Busby, and R. Woodward (Vernon et al., 2012), which demonstrated the overall viability of the USArray Transportable Array network for monitoring severe weather events in realtime;

2. "AlpArray - technical strategies for large-scale European co-operation in broadband seismology", by A. Brisbourne, J. Clinton, G. Hetenyi, C. Pequegnat, M. Wilde-Piorko, A. Villasenor, P. Comelli, and the AlpArray Working Group (Brisbourne et al., 2012), which illustrated the state-of-the art in organization and subprojects definition of the AlpArray new initiative to study the greater Alpine area with a large-scale broadband seismological network; 
Table 1. Oral Programme SM1.3/GI1.7.

\begin{tabular}{|c|c|c|}
\hline EGU Abstract ref. & Title & Authors \\
\hline EGU2012-10770 & $\begin{array}{l}\text { Integration of Infrasound, Atmospheric Pressure, } \\
\text { and Seismic Observations with the NSF Earth- } \\
\text { Scope USArray Transportable Array }\end{array}$ & $\begin{array}{l}\text { F. Vernon, J. Tytell, M. A. H. Hedlin, K. Walker, } \\
\text { R. Busby, and R. Woodward }\end{array}$ \\
\hline EGU2012-3615 & $\begin{array}{l}\text { Ireland Array: A new broadband seismic network } \\
\text { targets the structure, evolution and seismicity of } \\
\text { Ireland and surroundings }\end{array}$ & $\begin{array}{l}\text { S. Lebedev, C. Horan, P. W. Readman, } \\
\text { A. J. Schaeffer, M. R. Agius, L. Collins, } \\
\text { F. Hauser, B. M. O'Reilly, and T. Blake }\end{array}$ \\
\hline EGU2012-7107 & $\begin{array}{l}\text { Optimizing Site Selection in Urban Areas in } \\
\text { Northern Switzerland }\end{array}$ & $\begin{array}{l}\text { K. Plenkers, T. Kraft, F. Bethmann, S. Husen, } \\
\text { and M. Schnellmann }\end{array}$ \\
\hline EGU2012-3881 & $\begin{array}{l}\text { A Technique to Determine the Self-Noise of } \\
\text { Seismic Sensors for Performance Screening }\end{array}$ & H. Rademacher, D. Hart, and C. Guralp \\
\hline EGU2012-11345 & $\begin{array}{l}\text { AlpArray - technical strategies for large-scale } \\
\text { European co-operation in broadband seismology }\end{array}$ & $\begin{array}{l}\text { A. Brisbourne, J. Clinton, G. Hetenyi, C. Pequeg- } \\
\text { nat, M. Wilde-Piorko, A. Villasenor, P. Comelli, } \\
\text { and the AlpArray Working Group }\end{array}$ \\
\hline
\end{tabular}

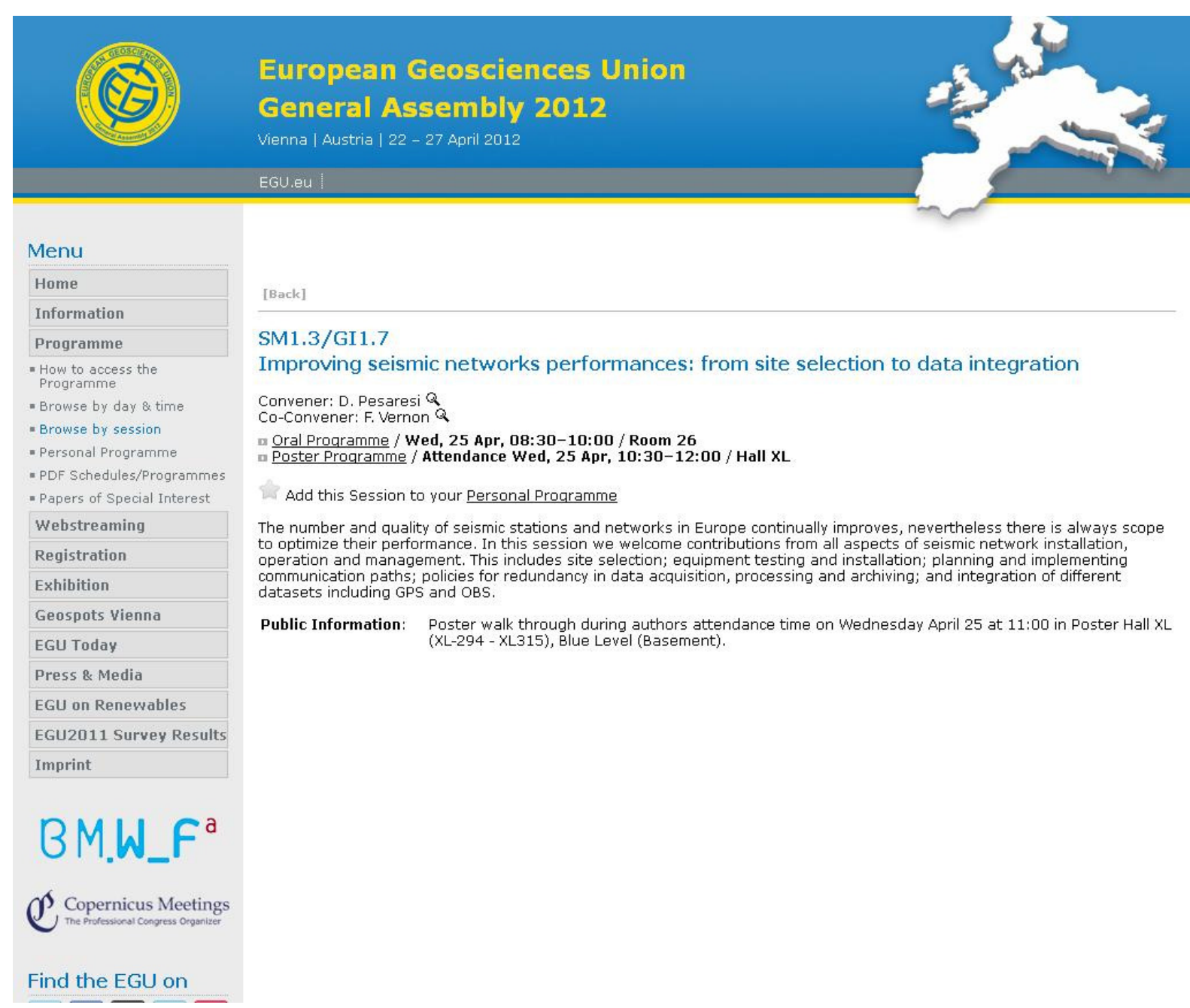

Fig. 1. EGU2012 SM1.3/GI1.7 session (from EGU2012 Homepage). 
Table 2. Poster Programme SM1.3/GI1.7.

\begin{tabular}{|c|c|c|}
\hline EGU Abstract ref. & Title & Authors \\
\hline EGU2012-1077 & $\begin{array}{l}\text { Seismic noise study for a new seismic station at King Fahd } \\
\text { University of Petroleum and Minerals in Saudi Arabia }\end{array}$ & S. I. Kaka \\
\hline EGU2012-2272 & $\begin{array}{l}\text { Role of the Egyptian National Seismological Network to } \\
\text { mitigate the seismic hazard in Egypt }\end{array}$ & A.-A. Mohamed \\
\hline EGU2012-2614 & $\begin{array}{l}\text { Improving identification of regional depth phases in sparse } \\
\text { networks }\end{array}$ & M.-T. Apoloner and G. Bokelmann \\
\hline EGU2012-3072 & $\begin{array}{l}\text { HIGH-RESOLUTION, LOW POWER, INTERGRATED } \\
\text { AFTERSHOCK and MICROZONATION SYSTEM }\end{array}$ & Dr. L. Zimakov and P. Passmore \\
\hline EGU2012-3376 & $\begin{array}{l}\text { Autonomous telemetry system by using mobile networks } \\
\text { for a long-term seismic observation }\end{array}$ & S. Hirahara, N. Uchida, and J. Nakajima \\
\hline EGU2012-3924 & Site effects in seismic data acquisition & Y. Jia, N. Horn, and W. Lenhardt \\
\hline EGU2012-6598 & Local magnitude scale in Slovenia & J. Bajc, Ž. Zaplotnik, M. Živčić, and M. Čarman \\
\hline EGU2012-7310 & $\begin{array}{l}\text { OGS improvements in the year } 2011 \text { in running the North- } \\
\text { eastern Italy Seismic Network }\end{array}$ & $\begin{array}{l}\text { P. L. Bragato, D. Pesaresi, A. Saraò, P. Di Bartolomeo, and } \\
\text { G. Durì }\end{array}$ \\
\hline EGU2012-7717 & $\begin{array}{l}\text { Geophysical monitoring of a complex geologic frame- } \\
\text { work: the multi-disciplinary sensor networks in Sicily } \\
\text { (Italy) }\end{array}$ & $\begin{array}{l}\text { M. Cantarero, S. Di Prima, M. Mattia, D. Patanè, and } \\
\text { M. Rossi }\end{array}$ \\
\hline EGU2012-7830 & $\begin{array}{l}\text { Kurtosis based automated P-S phase picking procedure for } \\
\text { hypocenter determination: Vanuatu region case study }\end{array}$ & C. Baillard, W. Crawford, V. Ballu, and C. Hibert \\
\hline EGU2012-8121 & Simulations of a Microearthquake Network & O. Valtonen, M. Uski, A. Korja, T. Tiira, and J. Kortström \\
\hline EGU2012-8654 & $\begin{array}{l}\text { S-onset time automatic picking based on polarization anal- } \\
\text { ysis and higher order statistics }\end{array}$ & A. Lois, E. Sokos, P. Paraskevopoulos, and G.-A. Tselentis \\
\hline EGU2012-9374 & $\begin{array}{l}\text { Broad-band seismometers in the extreme cold: what we } \\
\text { learn from the observatory station CCD (Concordia, } \\
\text { Antarctica) }\end{array}$ & J.-J. Lévêque, M. Bès de Berc, A. Maggi, and J.-Y. Thoré \\
\hline EGU2012-9468 & $\begin{array}{l}\text { Comparison of manual and automatic onset Time picking } \\
\text { for local earthquake in North Eastern Italy }\end{array}$ & D. Spallarossa, L. Tiberi, and G. Costa \\
\hline EGU2012-9523 & The Athens Acropolis Strong Motion Array & $\begin{array}{l}\text { I. S. Kalogeras, C. P. Evangelidis, N. S. Melis, and } \\
\text { K. Boukouras }\end{array}$ \\
\hline EGU2012-9764 & $\begin{array}{l}\text { Rigorous noise test and calibration check of strong-motion } \\
\text { instrumentation at the Conrad Observatory in Austria }\end{array}$ & $\begin{array}{l}\text { R. Steiner, G. Costa, W. Lenhardt, N. Horn, and } \\
\text { P. Suhadolc }\end{array}$ \\
\hline EGU2012-10922 & $\begin{array}{l}\text { Continuous GPS observations in Tohoku University and } \\
\text { recovery effort after the } 2011 \text { off the Pacific coast of To- } \\
\text { hoku Earthquake }\end{array}$ & $\begin{array}{l}\text { T. Demachi, S. Miura, Y. Ohta, K. Tachibana, S. Ueki, } \\
\text { T. Sato, M. Ohzono, and N. Umino }\end{array}$ \\
\hline EGU2012-11006 & $\begin{array}{l}\text { A new integrated approach to seismic network optimiza- } \\
\text { tion }\end{array}$ & A. Tramelli, G. De Natale, C. Troise, and M. Orazi \\
\hline EGU2012-11620 & $\begin{array}{l}\text { A noise comparison between two different types of sensor } \\
\text { installation }\end{array}$ & M. Langlais, B. Vial, and O. Coutant \\
\hline EGU2012-12370 & $\begin{array}{l}\text { Moment Tensor code for the Antelope Environmental } \\
\text { Monitoring System }\end{array}$ & J. Reyes, R. Newman, F. Vernon, and G. van den Hazel \\
\hline EGU2012-12521 & $\begin{array}{l}\text { Evaluation results after seven years of operation for } \\
\text { the permanent Hellenic Seismological Network of Crete } \\
\text { (HSNC) }\end{array}$ & F. Vallianatos, G. Hloupis, and I. Papadopoulos \\
\hline
\end{tabular}


3. "Site effects in seismic data acquisition", by Y. Jia, N. Horn, and W. Lenhardt (Jia et al., 2012), which shows how seismic signals depend on site effects, comparing recordings from three co-located seismic stations with different conditions: in a tunnel, free field and in a borehole;

4. "Broad-band seismometers in the extreme cold: what we learn from the observatory station CCD (Concordia, Antarctica)", by J.-J. Lévêque, M. Bès de Berc, A. Maggi, and J.-Y. Thoré (Lévêque et al., 2012), which illustrates calibration and operation of very broad band seismometers at very severe conditions in Antarctica with temperatures down to $-54^{\circ}$.

The papers published in these proceedings of the EGU2012 SM1.3/GI1.7 session are:

1. "OGS improvements in the year 2011 in running the Northeastern Italy Seismic Network", by P. L. Bragato, D. Pesaresi, A. Saraò, P. Di Bartolomeo and G. Durì, which shows the improvements made by OGS in terms of long period noise reduction and data link reliability in running a seismic network;

2. "Optimal configuration of a micro-earthquake network", by O. Valtonen, M. Uski, A. Korja, T. Tiira, and J. Kortström, which illustrates the method applied to plan a micro-earthquake network to monitor a power plant;

3. "Improvement of broadband seismic station installations at the Observatoire de Grenoble (OSUG) seismic network", by M. Langlais, B. Vial, and O. Coutant, which illustrates the improvement made at seismic network site to reduce long period noise above 20 seconds;

4. "The South Aegean Seismological Network - HSNC", by G. Hloupis, I. Papadopoulos, J. P. Makris and F. Vallianatos, which illustrates the installation and the technology applied for the operation of the Hellenic Seismological 12 Network of Crete (HSNC);

5. "Local magnitude scale in Slovenia", by J. Bajc, Z. Zaplotnik, M. Zivcic, and M. Carman, which illustrates a calibration study of the local magnitude $M_{\mathrm{LV}}$ scale in Slovenia;

6. "Seismic noise study for a new seismic station at King Fahd University of Petroleum and Minerals in Saudi Arabia”, by S. I. Kaka, which illustrates a seismic noise study to select a suitable site for a new broad band seismic station.

\section{Conclusions}

The quality and quantity of presentations made at the EGU2012 SM1.3/GI1.7 session well satisfied the expectations of the Convener and Co-Convener, and well fitted the goals of the European Geosciences Union.

The steady number of presentation at such yearly seismic networks sessions encourage the conveners that the path they followed in organizing such sessions is a valid one, and that there is need in the seismological community worldwide to present and discuss different solutions to common problems in running seismic networks.

Acknowledgements. The authors thank the authors of the EGU2012 SM1.3/GI1.7 session presentations, especially those who made the effort to publish their presentations in these proceedings on Advances in Geosciences: D. Pesaresi, O. Valtonen, M. Langlais, F. Vallianatos, J. Bajc and S. I. Kaka.

\section{References}

Brisbourne, A., Clinton, J., Hetenyi, G., Pequegnat, C., WildePiorko, M., Villasenor, A., Comelli, P., and the AlpArray Working Group: AlpArray - technical strategies for large-scale European co-operation in broadband seismology, EGU General Assembly, Vienna, Austria, 22-27 April 2012, EGU2012-11345, 2012.

Jia, Y., Horn, N., and Lenhardt, W.: Site effects in seismic data acquisition, EGU General Assembly, Vienna, Austria, 22-27 April 2012, EGU2012-3924, 2012.

Lévêque, J.-J., Bès de Berc, M., Maggi, A., and Thoré, J.-Y.: Broadband seismometers in the extreme cold: what we learn from the observatory station CCD (Concordia, Antarctica), EGU General Assembly, Vienna, Austria, 22-27 April 2012, EGU2012-9374, 2012.

Pesaresi, D.: The EGU2010 SM1.3 Seismic Centers Data Acquisition session: an introduction to Antelope, EarthWorm and SeisComP, and their use around the World, Ann. Geophys., 54, 1-7, doi:10.4401/ag-4972, 2011.

SM1.3 Seismic Centers Data Acquisition, available at: http: //meetingorganizer.copernicus.org/EGU2010/session/2427 (last access: 26 March 2013), 2010.

SM1.3/G3.8/GD3.7/GI-19/TS8.7 Improving seismic networks performances: from site selection to data integration, available at: http://meetingorganizer.copernicus.org/EGU2011/session/ 7340 (last access: 26 March 2013), 2011.

SM1.3/GI1.7 Improving seismic networks performances: from site selection to data integration, available at: http: //meetingorganizer.copernicus.org/EGU2012/session/10081 (last access: 26 March 2013), 2012.

Vernon, F., Tytell, J., Hedlin, M. A. H., Walker, K., Busby, R., and Woodward, R.: Integration of Infrasound, Atmospheric Pressure, and Seismic Observations with the NSF EarthScope USArray Transportable Array, EGU General Assembly, Vienna, Austria, 22-27 April 2012, EGU2012-10770, 2012. 